\title{
Out-of-School Reading and Literature Discussion: An Exploration of Adolescents' Participation in Digital Book Clubs
}

\author{
Jamie Colwell \\ Old Dominion University \\ Lindsay Woodward \\ Drake University \\ Amy Hutchison \\ George Mason University
}

\begin{abstract}
This research used an inductive qualitative method to examine how adolescents participated in online literature discussion, with limited guidance from adults, through a summer reading program. Using a New Literacies framework, the authors considered that literacy is social and collaborative and that adolescents often engage in such literacy practices on the Internet outside of school. This study considered these literacy practices to examine an eight-week voluntary online summer reading program at a public library and how such a program might inform such activities in school settings to promote more authentic opportunities for literacy engagement. In this program, 12 adolescents (ages 13-17) read print-based young adult novels and responded to their reading in threaded discussion boards, called book clubs, in a closed, online social network. Results indicated two overlapping themes related to students' formality in writing that promote shared learning and personalize digital discussions to make connections. Researchers found adolescents spontaneously adopted online discussion techniques that hybridized formal discussion practices with more personal practices to encourage emotive transaction with text. These results raised implications for integrating such activities in classroom settings to support all learners and to promote academic literacies.
\end{abstract}

Keywords: digital book clubs, adolescents, literature discussion

Colwell, J., Woodward, L., \& Hutchison, A. (2018). Out-of-school reading and literature discussion: An exploration of adolescents' participation in digital book clubs. Online Learning, 22(2), 221-247. doi:10.24059/olj.v22i2.1222 
Out-of-School Reading and Literature Discussion:

An Exploration of Adolescents' Participation in Digital Book Clubs

\section{Out-of-School Reading and Literature Discussion: An Exploration of Adolescents' Participation in Digital Book Clubs}

Today's adolescents live and participate in a digital world, connected by numerous social technologies that support continuous sharing and discussion of information online. These social digital tools are often appealing because they afford adolescents opportunities to build relationships and adopt roles to interact with others online (Alvermann et al., 2012). For example, online social networks can facilitate a host of sharing and discussion features that encourage students to navigate online spaces, assume online identities, and voice opinions using digital text (Lankshear \& Knobel, 2011; Leu, Kinzer, Coiro, Castek, \& Henry, 2013). Studies targeted at understanding how adolescents engage in such online practices build on scholarship within the New Literacies Studies and employ the view that literacy is social, collaborative, and situated (Gee, 2004; Street, 1993). Further, adolescents frequently engage in rich collaborative and social literacy practices on the Internet outside of school (Hutchison \& Henry, 2010). Thus, it is useful to study adolescents' authentic engagement in online communities in out-of-school settings to consider the literacies that students bring with them to school contexts (Alvermann, 2008; Buck, 2012). To examine these issues, the current study focused on adolescents' engagement in asynchronous book club discussions about young adult (YA) literature in an online social network (OSN) developed for a public library's online summer reading program and focused on the following research question: How do adolescents participate in asynchronous online book club discussions about literature with limited guidance from adults?

\section{Review of Related Literature}

The current study is first informed by the idea that "knowledge construction is a situated process that includes social and cognitive interactions ranging from simply sharing information, to negotiating meanings, to summarizing and synthesizing new knowledge" (Oztok, 2016, p. 158). As such, peer discussion and interaction play a critical role in how a learner will come to understand a concept or topic and how they learn particular ways of speaking within a domain of activity (Gee \& Hayes, 2013). Such an understanding of knowledge construction emphasizes the role of engagement, participation, and membership in a community and discredits the idea that learning is an in-the-head phenomenon (Nasir \& Cooks, 2009). Considering the role that digital technology plays in adolescents' lives, much of the discussion, interaction, and community participation in which adolescents engage often takes place online. New Literacies theory, which addresses the transformation of literacy skills in digital spaces (Gee, 2004; Lankshear \& Knobel, 2007), reinforces this idea, with the scholars arguing that digital youth

seek out memberships and peers in areas of affinity and interest, and pursue different kinds of relationships between "authors" and "audiences" from those characterizing many conventional literacy practices. They generally value attending to the interests and knowledge of others, recognize that quality is judged by groups rather than appointed experts, welcome diversity of opinion in decisionmaking, and so on. (p. 98)

As such, new literacies are those skills that are necessary for students to successfully navigate and engage in digital reading and writing practices (e.g., navigating digital hyperlinked texts and responding to those texts using digital tools) and that differ from skills necessary for traditional practices (e.g., paper-based composition and print-based reading and comprehension) that define 
literacy. Such skills are important to creating more literate adolescents in the 21 st century (Leu et al., 2013). Accordingly, adolescents' participation in an online social network and an analysis of their interactions and discussion in that digital space was the focus of the current study, in which adolescents participated in an online summer reading program. From an academic standpoint, online discussion has much to offer. When used in school settings, online discussion with peers has prompted upper grade students to write more comprehensive responses to print literature compared to traditional pen-and-paper writing activities (Grisham \& Wolsey, 2006) and provide thoughtful analyses of others' responses due to the additional time provided by an asynchronous structure (Larson, 2009; Day \& Kroon, 2010). Further, students are more likely to return to the text and generate deeper and more meaningful text-driven interactions in such online environments (Larson, 2009; Wolsey \& Grisham, 2007). Additionally, students can use combinations of formal and informal language to communicate their interpretations and how they are positioning themselves as readers dialoguing in a digital space (West, 2008). In sum, online discussion can provide a voice for each student to deeply reflect on text in a setting that encourages all students to participate (English, 2007; West, 2008).

Although the literature regarding online discussion in school settings informs the current study, we were primarily interested in how adolescents participate in online book clubs when these discussions are not accompanied by explicit academic instruction. Our interest was driven by the notion that such participation may offer more genuine discussion and engagement in online settings, which may in turn inform methods for more authentic instruction in classroom settings. Although online discussion may sometimes result in shallow discussion or unsupported opinions, discussion in an anonymous online setting may allow adolescents to take on unique identities, express opinions, and adopt practices particular to the space in which they engage (Alvermann, 2008; Alvermann et al., 2012; Black, 2009; Stewart, 2014), and such practices shape online interactions. Many of these practices involve collaboration as adolescents trade digital data, such as images, and engage with others to build digital resources (Leander \& Frank, 2006). Other online practices align more with social roles as adolescents engage with one another to offer support in common interests (Alvermann et al., 2012), an idea which is pertinent to this study, as these roles may influence students' participation in and the subsequent angle of discussion.

One of the ways that adolescents participate in online discussion and take on new roles is through affinity spaces. Online affinity spaces are sites of informal learning among people drawn together by a shared interest and opportunity to learn with others (Padgett \& Curwood, 2015). Gee (2005) argued that affinity spaces are an important form of social affiliation, with which young people are particularly familiar and in which effective informal learning occurs. Further, affinity spaces provide a place where users can pick up "practices through joint action with more advanced peers, and advance their abilities to engage and work with others in carrying out such practices" (Gee, 2004, p. 70). Examples of affinity spaces include sites such as Figment (figment.com), where adolescents read, write, and critique poetry, and fan fiction sites, such as wattpad.com and fanfiction.net, where writers create and receive feedback on new stories based on existing stories, characters, or settings. Affinity spaces provide rich opportunities for youth to write for an authentic audience of peers interested in the same topic. For example, as Curwood's (2013) study highlighted, a fan fiction OSN can support adolescents' active engagement in text, specifically critical consideration of events, themes, and literary techniques, through reflection and sharing of opinions with others interested in the same discussion topic. Such findings were important as we considered how the asynchronous nature of the book club discussions might support or inform 
students' various viewpoints about the literature they read in a setting outside of school with little teacher influence and few guidelines for response.

A discussion of affinity spaces is particularly germane to the current study because the online social network students used to participate in the book clubs in this study was similar to an affinity space. However, our book clubs differed in important ways and fill a gap in the literature related to adolescents' online participation. Adolescents in the current study were not participants in any affinity spaces, such as fan fiction sites, when they enrolled in the study and thus were not involved in any out-of-school discussions or activities about the literature they were reading outside of the summer reading program. Many adolescents may be unaware of sites such as Figment or Wattpad or may not be inclined to seek out such sites on their own. Yet these adolescents may enjoy and benefit from participation in online discussions about literature that take place outside of school. As such, we designed and studied online book clubs that youth could participate in through the public library during the summer, a time when they may desire opportunities to engage in literature discussion. It is important to study adolescents' engagement in these informal, out-of-school online book clubs because participants were not given guidance on how to participate or respond, but rather were only given general response prompts. Studying adolescents' participation in these online book clubs informs us about how adolescents naturally participate in this setting, which is informal and similar to affinity spaces, but by virtue of being offered through the public library is somewhat academic in nature. Understandings of adolescents' participation in this setting can illuminate ways to (1) engage students who do not belong to affinity spaces in out-of-school literacy activities but who actively engage in online discussion about literature and (2) connect students' out-of-school online discussion activities to what they do in the classroom.

\section{Methods}

The purpose of this study was to explore adolescents' voluntary participation in online book clubs with limited guidance from adults. To do so, after receiving Institutional Review Board approval, multiple sources of data were collected during an eight-week online summer reading program and analyzed using a general inductive qualitative approach (Thomas, 2006).

\section{Description of Context and Participants}

The program was hosted at a public library that expressed interest in an online program to encourage adolescent participation in summer reading. The library was located in a midsize city in the southeastern region of the United States and has 13 locations throughout the city that provide access to print and digital materials and technological resources. The researchers collaborated with the Youth and Teen Services Director to develop the program and recruit students. Participation was voluntary, and participants were recruited through the library's summer reading program flier and website. Sixteen adolescents (ages 13-17) attended the orientation meeting for the program and registered to participate in the summer program. However, four adolescents who registered never posted in any of the discussion forums. Thus, only the 12 adolescents (10 females and 2 males) who posted in the book club forums were considered participants. Hereafter, we refer to the participants as "students" because we considered them active learners in this summer reading program. Ten students identified as Caucasian, one as Asian-American, and one student as African-American. Only two students indicated in the orientation meeting that they knew each other prior to the online summer reading program. Table 1 provides an overview of participants. 


\begin{tabular}{lll}
\hline $\begin{array}{l}\text { Table } 1 . \\
\text { Book Club Participants }\end{array}$ & & \\
\hline Pseudonym & Gender & Age \\
\hline Hallie & Female & 13 \\
Melissa & Female & 13 \\
Bryce & Female & 13 \\
Lexi & Female & 13 \\
Amy & Female & 13 \\
Frank & Male & 13 \\
Paige & Female & 13 \\
Trish & Female & 13 \\
Bonnie & Female & 14 \\
Grey & Male & 14 \\
Chloe & Female & 17 \\
Sam & Female & 17 \\
\hline
\end{tabular}

Because this study was conducted outside of a school setting, data regarding students' socioeconomic status and school-related literacy skills were unavailable. Further, the orientation meeting was held at the main branch in the city center. This branch was not necessarily the branch all students used on a regular basis, which further limited our understanding of their socioeconomic status. However, we do note that a parent for each student attended the program's orientation meeting with their child, and all students indicated that they owned a computer.

The purpose of the orientation was to familiarize students with the OSN, provide an overview of the books that could be discussed, and collect informal data regarding students' motivation to participate in online book clubs and self-perceptions of their reading ability. To do so, we used the Adolescent Motivation to Read Profile (AMRP; Pitcher et al., 2007) and an openended survey regarding reading and online interests and habits (see Appendix A). These data provided a window into students' reading habits and perceptions of their reading ability prior to the study and provide context. All the participants reported they were "good" to "very good" readers. Six students indicated their participation was based on an interest in reading and participating in a book club that was online. The remaining students responded that they were participating in the summer reading program for the following reasons: (a) parent influence/requirement (two students); (b) the program fulfilled a requirement for community and service hours for their school (two students); or (c) the program fulfilled a summer reading requirement for their school (two students). However, survey results indicated that all students were enthusiastic to join the program and discuss literature with others, which somewhat mitigated differences in motivation to participate. 


\section{Description of the Online Summer Reading Program}

A Ning network was selected as the OSN because of its appealing user interface and safe, private online setting that supported multiple group interactions. The network hosted a discussion forum, which facilitated multiple topical discussion threads, where all online discussion was held. Students could easily access all of the discussion threads from the discussion forum and were invited to participate in multiple forum discussions if they chose.

The online book clubs. We adopted the term book clubs to describe the discussion threads hosted in the forums on the OSN. Although multiple traditional models exist, we referred to Daniels's (2002) description of a book club as a group of K-12 students who gather to discuss a common work of literature. These book clubs are formed around students' interest in reading a particular book rather than their level of reading achievement. Specifically, Daniels described book clubs as "open, natural conversations about books" (p. 18). In keeping with book clubs as described by Daniels, students selected the book they read, engaged in small group discussions based on book choice, and determined their own discussion topics. Though many associate Daniels's model of book clubs with assigned roles and role sheets (e.g., connector, literary luminary) to guide discussions of literature, he argued that such roles could be a temporary scaffold but need not be a permanent structure in discussion groups. Given the informal out-of-school setting for our study, we opted not to use assigned roles and role sheets; rather, students selected their own roles and engaged in discussion as they felt comfortable.

Yet, moving book clubs online, particularly in out-of-school settings, fundamentally alters the literacy practices and the manner in which students must navigate discussion to be active participants and the lens through which we study such practices (Moje, 2009). Thus, we also considered Larson's (2009) approach to online literature discussion about print-based texts in a fifth-grade class to further situate and organize online book clubs. Online book clubs may be appealing to adolescents who regularly participate in digital practices (Scharber, 2009), but summer reading programs must also offer texts adolescents find interesting to voluntarily participate in such a program (Allington \& McGill-Franzen, 2013). Additionally, we considered that contemporary young adult (YA) titles would likely be most appealing to students given the relevance of such books to their lives (Ivey \& Johnston, 2013). We, along with the Youth and Teen Services Director at the library, utilized these concepts to offer students five book clubs to participate in, hosted in separate discussion threads on the Ning, which were distinguished by genre (i.e., Graphic Novels, Ghost Stories and Hauntings, Dystopian, Chick Lit, and Action \& Suspense). Each genre contained four or five novels. The director guided this selection, as one of her primary roles in the library was to research and select popular YA literature to motivate adolescents to engage in reading outside of school. Table 2 outlines the book clubs and the books read in each. 


\begin{tabular}{|c|c|}
\hline \multicolumn{2}{|l|}{ Book Club Titles } \\
\hline Book Club Genre & Titles and Authors \\
\hline Action \& Suspense & $\begin{array}{l}\text { Au Revoir, Crazy European Chick (Schreiber, 2011) } \\
\text { Altered (Rush, 2013) } \\
\text { Dust Lands: Blood Red Road (Young, 2012) } \\
\text { The Girl Who Could Fly (Forester, 2010) }\end{array}$ \\
\hline Chick Lit & $\begin{array}{l}\text { Almost Home (Bauer, 2013) } \\
\text { I'd Tell You I Love You, but Then I'd Have to Kill You } \\
\text { (Carter, 2007) } \\
\text { Twice Upon a Time: Rapunzel (Mass, 2012) } \\
\text { The Teashop Girls (Rim, 2009) }\end{array}$ \\
\hline Ghost Stories and Hauntings & $\begin{array}{l}\text { Wait Till Helen Comes (Hahn, 2008) } \\
\text { Amber House (Moore, Reed, \& Reed, 2013) } \\
\text { Haunted [Name of City Blinded] } \\
\text { The Ghost of Graylock (Poblocki, 2012) }\end{array}$ \\
\hline Graphic Novels & $\begin{array}{l}\text { Tiny Titans (Baltazar, 2009) } \\
\text { Amulet (Kibuishi, 2008) } \\
\text { Wonderstruck (Selznick, 2011) } \\
\text { Maus (Spiegelman, 1986) } \\
\text { A Monster Calls (Ness \& Kay, 2013) }\end{array}$ \\
\hline $\begin{array}{l}\text { If You Liked The Hunger } \\
\text { Games (Dystopian) }\end{array}$ & $\begin{array}{l}\text { Graceling (Cashore, 2009) } \\
\text { Delirium (Oliver, 2012) } \\
\text { The Maze Runner (Dashner, 2010) } \\
\text { The Selection (Cass, 2013) }\end{array}$ \\
\hline
\end{tabular}

Discussion in the book clubs. To participate in discussion, students set up an account on the Ning, using a self-selected screen name that did not include their first or last name for anonymity. We offered students the opportunity to change book clubs at any time during the summer if they decided to read a book from a different genre, and they could participate in more than one book club at a time. A schedule was created for book club discussions that allowed students 10 days to read a book and five days to engage in online discussion about the book through asynchronous written posts on a designated forum. A screenshot of a sample book club page, with identifying information removed, is provided in Figure 1. 


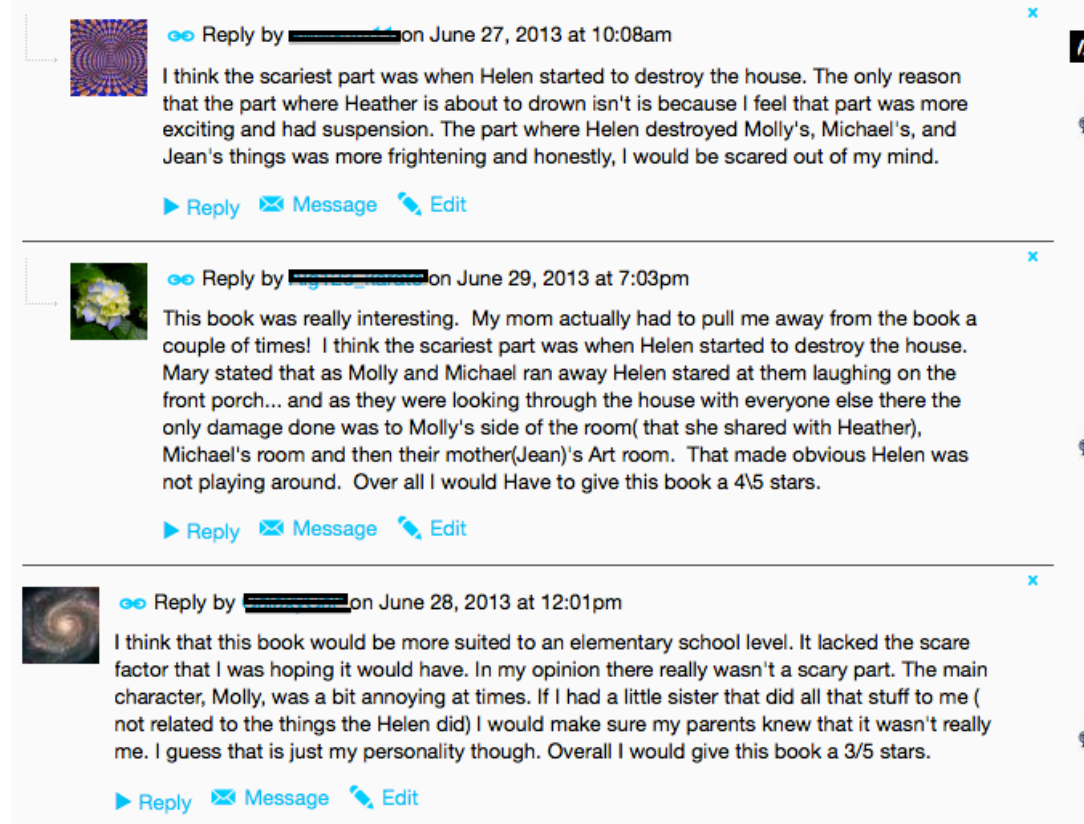

Figure 1. Sample book club page.

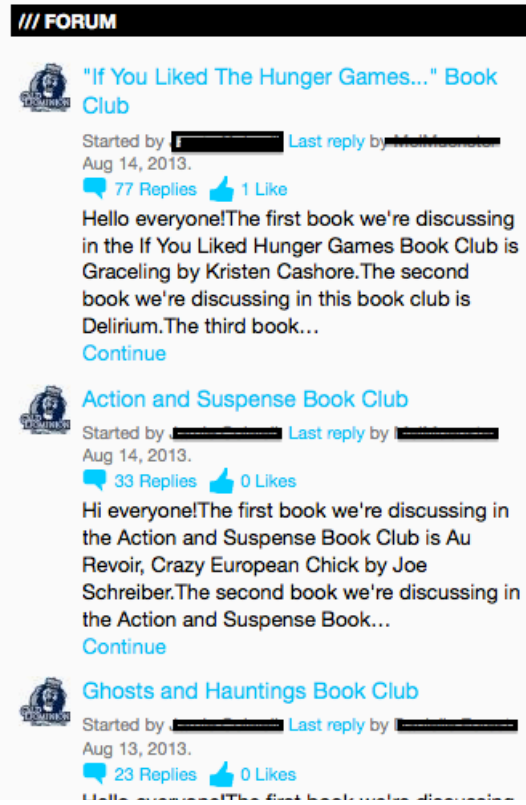

Students were invited to read only one book in one genre per discussion cycle. Yet, eight students read multiple books and participated in multiple book clubs during each cycle. We acted as participant observers (Patton, 2002) and facilitated discussion by posting general opening prompts to spark discussion (e.g., "What interested you most about this novel?") and posing follow-up questions only if discussion stalled. We decided prior to the program that if a book club had only one participant, we would engage in discussion with that student, but would not consider that discussion in data analysis. This decision was moot, however, as every book club had at least three participants throughout the program. On average, researchers posted content-related responses only one time, aside from the initial prompt, during discussion.

\section{Data Sources and Collection}

Data sources included the prestudy AMRP (Pitcher et al., 2007) and corresponding openended survey questions described in a previous section and all book club discussion posts on the OSN. Student discussion posts were considered primary sources of data to address the research questions. Discussion posts unrelated to content of books, such as reminders of upcoming book discussion dates or students/researcher online conversation regarding the availability of a book title at a certain library branch, were excluded from this count. Table 3 provides a breakdown of the number of posts made by each student in each book club. 


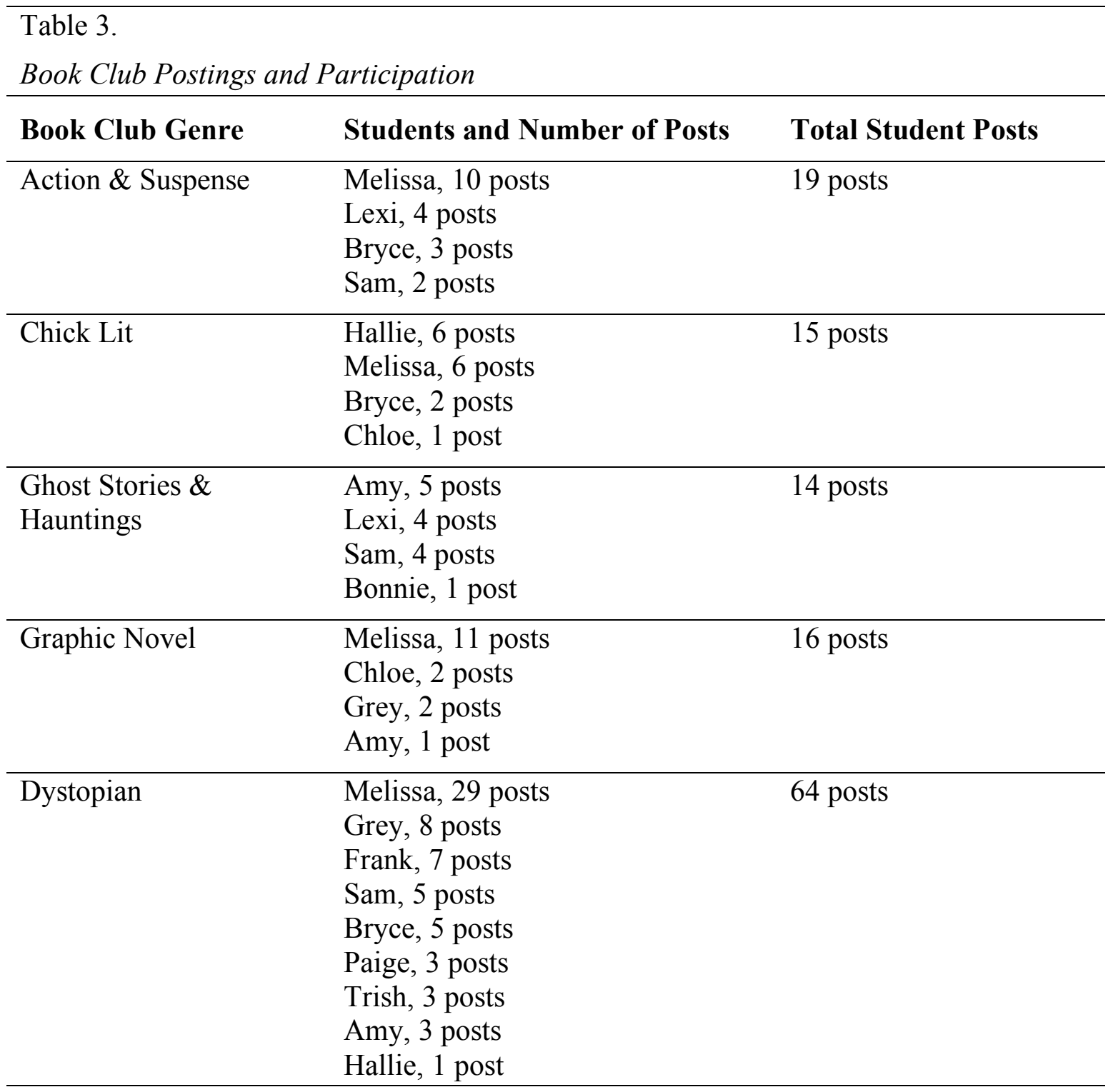

128 total posts

The Dystopian book club was the most popular and generated the most discussion, but consistent participation was also observed in the other online book clubs. We also note that one student, Melissa (this and all other names are pseudonyms), posted more frequently than any other student. Length of posts in each book club remained consistent across book clubs and throughout the program, with an average of three complete sentences per post. There were only three instances of two-word, nondescriptive responses (i.e., "Me too!" and "I agree."). The remaining data sources were used in triangulation to confirm, disconfirm, and inform themes that emerged from the data.

\section{Data Analysis}

We used a general inductive approach to qualitative data analysis (Thomas, 2006). To address our research questions regarding students' roles and new literacies, we used this approach "to allow research findings to emerge from the frequent, dominant, or significant themes in raw 
data" (Thomas, 2006, p. 238). Discussion posts were our primary data source; posts were transferred to Word documents, and separate transcripts were created for each of the five book clubs. We then read through every transcript once to gain a holistic understanding of the data. After this first reading, we decided to code all five transcripts as a whole because (a) discussions were similar across book clubs in that students responded primarily to their interests, understandings, and questions about the books, and (b) we wanted to consider the summer reading program as a whole. This decision was grounded in the idea that "inductive coding begins with close readings of text and considerations of the multiple meanings that are inherent in text" (Thomas, 2006, p. 241). Thus, we wanted to conduct a "close reading" of all book club discussion data considered in this study to look for overall themes that might emerge from online literature discussion, rather than look at each book club as a separate entity. Further, the multiple conversations happening in each genre's discussion thread constituted one connected discussion space because students participated in multiple book clubs during the summer reading program. This decision allowed for coding transcripts holistically to summarize raw data (Thomas, 2006). Coding thus began during the second holistic reading of transcripts. These codes were considered and collapsed into themes relevant to our research questions. Specifically, we developed codes and then determined links or relationships between codes that were relevant to our research questions; these relationships emerged into the themes that organize our findings. Themes were then further informed by openended survey data to better understand students' participation and discussion in the book clubs. To organize codes and relationships, we created tables to describe each code and note data that corresponded to each code for reference as we worked through data. Table 4 outlines our coding process of themes, codes, code descriptions, and corresponding data samples. 
Table 4.

Sample Coding Scheme

\begin{tabular}{|c|c|c|c|}
\hline Theme & Code & Code Description & Sample Corresponding Data \\
\hline \multirow[t]{3}{*}{$\begin{array}{l}\text { Personalizing } \\
\text { Digital } \\
\text { Discussion }\end{array}$} & $\begin{array}{l}\text { Emotional } \\
\text { Connections }\end{array}$ & $\begin{array}{l}\text { Response explains a } \\
\text { specific personal or } \\
\text { emotional connection to } \\
\text { an element in the book. }\end{array}$ & $\begin{array}{l}\text { "I think it is because he wanted } \\
\text { to make his father proud. } \\
\text { Every kid, no matter how mean } \\
\text { their parents may or may not } \\
\text { be, still wants their parents to } \\
\text { be proud of them, even if that } \\
\text { means giving up on things they } \\
\text { love to do." }\end{array}$ \\
\hline & $\begin{array}{l}\text { Communicating } \\
\text { Reactions }\end{array}$ & $\begin{array}{l}\text { Response demonstrates } \\
\text { an attempt to relay } \\
\text { personal reactions or } \\
\text { emotions through digital } \\
\text { text features. }\end{array}$ & $\begin{array}{l}\text { "In the book they refer to the } \\
\text { heart as fragile... Maybe that's } \\
\text { why they get the } \\
\text { operation...It's because these } \\
\text { people might be scared of heart } \\
\text { break...The operation } \\
\text { may fix all their heart break, } \\
\text { but the operation could never } \\
\text { really save each person } \\
\text { that gets the operation from } \\
\text { "the horrible disease" called } \\
\text { love, because we need love } \\
\text { to learn lessons, to protect, and } \\
\text { to live life." }\end{array}$ \\
\hline & $\begin{array}{l}\text { Relating to } \\
\text { Characters }\end{array}$ & $\begin{array}{l}\text { Response discusses a } \\
\text { specific connection to } \\
\text { character experiences or } \\
\text { interaction with setting } \\
\text { through an imagined } \\
\text { interaction in the book. }\end{array}$ & $\begin{array}{l}\text { "When we first met Macey I } \\
\text { really didn't like her and when } \\
\text { Cammie's mom came up with } \\
\text { excuses to have Macey in the } \\
\text { school, I was running through } \\
\text { possible } \\
\text { comebacks in my head." }\end{array}$ \\
\hline
\end{tabular}

\section{Results}

Two primary themes related to adolescents' participation in online book clubs emerged from analysis: (a) formality to promote shared learning and (b) personalizing digital discussion to make connections. Although distinct in analysis, we note here that overlap existed between these themes. For example, students used formal discussion techniques to convey personal and emotional reactions in discussion, hybridizing formal and personal discussion, a concept we explore further in the discussion. However, to fully examine both themes, we describe them separately as findings to better illustrate each theme.

\section{Formality to Promote Shared Learning}


Formal writing in discussion. Analysis indicated, with the exception of a few posts, that students almost solely employed formal language in their book discussions to clearly convey their response to literature. Characteristics of formal language reflected an academic approach to language and conventions, rather than informal language containing abbreviations, emoticons, and acronyms (West, 2008). Not only did they respond formally in the mechanics of their responses, such as using proper spelling and grammar, but more importantly through using language particular to academic environments. For example, students rarely included emoticons (two instances were noted), acronyms, abbreviations, or other conventions that are often present in online, informal discussions among teenagers (Crystal, 2001; Turner, Abrams, Katic, \& Donovan, 2014), suggesting the online book clubs promoted an awareness of academic, Standard Written English (Grisham \& Wolsey, 2006), seemingly to promote a learning-centric online discussion environment, even outside of an academic sphere.

We recognize that students may have viewed the public library and our status as university faculty as being associated with formal institutions, which may have influenced their language and formality, and we must consider that the setting and our roles had some influence on their use of formal language. However, we remained on the periphery of the discussion, only noting the transition from one book discussion to the next, and we encouraged students in the orientation to make the online space their own discussion space, posting ideas and opinions as they saw appropriate without the limitations that often exist in a school environment. Yet, students in this study used formal conventions of writing to clearly explain their ideas to an audience of peers. We noted the primary form of informal writing that appeared in students' responses was the use of ellipses to indicate thoughtfulness, rather than the omission of material. For example, Paige wrote about her connection to Graceling and utilized ellipses to indicate contemplation: "I would prefer unorganized and unplanned future more because I like surprises. If I knew what was going to happen every day it would get a little boring...you know?" (July 15, 8:36 p.m.). With the exception of nonstandard use of ellipses and capitalization in some places to express emotion, there was little evidence of intentional informal writing in the book club. Overall, students seemed concerned with communicating with multiple readers as clearly as possible and utilized formal writing and academic writing conventions to do so.

Additionally, students were careful to remain purposeful in their comments and used language and grammar that were accessible to other members of the online group. For instance, students discussed the theme of love in the Dystopian book club after reading the book Delirium, and their comments were clear and focused:

Bryce: I most definitely would not want to live in the Delirium world. Love isn't a disease and [should] be encouraged, not crushed. (July 11, 7:44 p.m.)

Trish: Love isn't something that can be cured. Love is something that is not only in your mind and in your heart, but it's in your spirit. That's not something I would give up for anything. (July 15, 3:21 p.m.)

Grey: In the book they refer to the heart as fragile.... Maybe that's why they get the operation.... It's because these people might be scared of heart break. The operation [to keep people from feeling love] may fix all their heart break, but the operation could never really save each person from "the horrible disease" called love, because we need love to learn lessons, to protect, and to live life. (July 16, 8:46 a.m. Ellipses added to indicate excerpt.) 
Each of these three students demonstrated strong academic writing, and all three indicated a clear understanding of the previous post(s). Further, this exchange highlighted students' understanding of audience, communication, and that different interpretations are acceptable in literature discussion, which are often foci of academic discussion in English. Although Grey did not include page numbers for his direct references in the book, he seemed aware that using examples from the text is a useful tool when defending a claim, which is common in academic writing and supported in widely adopted ELA standards (see National Governors Association, 2010). Bryce also utilized the text to engage others in a discussion of theme of emotional safety in a parallel discussion about the same book, Delirium. She drew on the setting of the story to make her claim: "Now no one is perfect, and in this world in the story they're trying to make everyone 'safe' and 'perfect'. Would any of you want to be a person nothing like themselves?" (July 15, 9:12 a.m.). These examples demonstrate that students extended their use of language beyond the colloquial and into the academic to engage with other students, which promoted shared learning in the online book clubs. Yet, according to Turner and colleagues (2010), the use of formal writing conventions is not always common in adolescents' online writing.

Students were also concerned with fully understanding each other's posts and, when there was the possibility of multiple interpretations, using concise and formal language to identify the author's purpose. Melissa and Grey had a brief conversation about a plot point in the book Graceling, which demonstrates how multiple interpretations were resolved:

Melissa: Do you think when a Graceling is born and has two different colored eyes that another person with a Grace has the same two colors? (July 28, 10:45 a.m.)

Grey: What do you mean? If the two people are born with the same Grace I do not think they would have the same eyes (if that is what the question meant). (July 28, 11:55 a.m.)

Melissa: I mean, if they had a Grace, any Grace, do you think there is [sic] at least two people with same exact colors? (July 28, 1:44 p.m.)

Grey: I really doubt it. There are so many possible color combinations out there. (July 28, 8:57 p.m.)

Grey wanted to engage Melissa in the conversation but was unclear as to her intent with the question. Thus, he explained his answer by identifying his own interpretation of her question in his response. Both Melissa and Grey demonstrated an attentiveness to audience in this exchange, as they sought to draw on common background knowledge in order to clarify and further their questioning.

Additionally, students revealed an awareness of writing and language by using specific literary terms or noting text features, akin to those that might be found in dialogue in a classroom setting. When describing Graceling, Sam drew on literary terms in her explanation of feelings about the book: "The Hunger Games is a Young Adults [sic] Dystopian novel and although this book would fit under the category of a Dystopian novel, when I think about a novel similar to the Hunger Games I think more of a post apocalyptic setting" (June 28, 11:53 a.m.). Sam focused here on genre and drew on characteristics of setting to explain her claim that she did not feel the book was appropriately placed in the Dystopian book club. Similarly, students also discussed how specific book features, such as images, supported their consideration of text. Amy noted, "I felt 
the graphics [in A Monster Calls] made me understand more about what the kid was feeling, the creepiness, sadness, and loneliness really shined through them" (August 12, 5:01 p.m.).

Formal facilitation of discussion. Students also spontaneously utilized more formal academic classroom techniques to facilitate and guide online discussion, often adopting roles that teachers frequently employ in face-to-face classroom discussions of literature, such as facilitators (see Short, Kaufman, Kaser, Kahn, \& Crawford, 1999, for a full description of roles). In an attempt to facilitate discussion and keep exchanges moving forward, some students posed formal, efferentresponse questions focused on textual, nonpersonal topics commonly used by teachers to prompt discussion (Short et al., 1999), throughout the book clubs. Yet, this type of formality often restricted, rather than promoted, discussion. For example, in response to the graphic novel Maus, Grey questioned, "Can anyone else name any other differences from what they read in this book set in the 1940s in Europe to today in America?" (July 30, 12:12 p.m.). Such questioning was used to elicit specific and direct text responses from book club members in a manner similar to that of an Initiate-Response-Evaluate (IRE; Mehan, 1979) model in which a teacher poses direct questions to students to evaluate their knowledge on a particular topic.

Some students posed similar questions to target connections found within the literature. Melissa posed one such question when she responded in the Action \& Suspense book club forum: "I thought the craziest part [of Au Revoir, Crazy European Chick] was when after Gobi killed someone she would act as calm as can be and wouldn't explain why she killed them. Did anyone see a relation to the title of the chapter and the chapter?" (June 28, 10:38 p.m.). Questions such as Melissa and Grey's often seemed out of place in the mostly fluid online discussion and failed to stimulate response from book club members. While no group member responded to Grey's question about Maus, Melissa's question elicited only one response: from Sam, who wrote, "Hey, finally finished the book today. I agree with you that the craziest part was how nonchalant Gobi was after killing someone. That was downright creepy." (June 29, 5:38 p.m.). Sam's response only addressed only Melissa's opinion about the novel, not her question, which was also found in students' responses that followed similarly focused questions. Although both discussions continued after these questions were posted, the questions were not referenced or addressed by other group members. Therefore, these types of questions were a way that some students attempted to more formally facilitate discussion, but it did not prove to be an effective approach to meaningful discussion in this setting. Thus, formality served students well in their attempts to convey their own connections to the text and engage in conversation about compelling aspects of the text, but it was less successful when used to mimic teacher-led discussion questions. However, students also facilitated discussion by asking personal questions and drawing text-to-self connections, which prompted rich discussion about books and is described in the second thematic section.

\section{Personalizing Digital Discussion to Make Connections}

Emotion as expression. Although students used formal language and sometimes employed teacher-like approaches to facilitating discussion, perhaps in part due to the program's library affiliation and our university affiliation, they often simultaneously shared emotional responses to literature that personalized the online book clubs and expressed their connections to literature. These emotional responses that made us consider that the library's and our roles may not have been as influential in their discussion. These responses revealed sometimes raw emotional responses to their readings and expressed personal reactions we considered outside of the norm for formal settings. While they continued to facilitate discussion by posing questions and prompting 


\section{Out-of-School Reading and Literature Discussion: \\ An Exploration of Adolescents' Participation in Digital Book Clubs}

responses from one another, many of these questions elicited responses that forged personal connections with one another. For example, participants discussed emotional connections with books, and several stated they cried in response to a book and likened those responses to those they had when reading other popular YA novels not on the book club reading lists. For example, some students, such as Bryce, discussed crying during sad scenes: "It was so touching that I actually cried when Alex was shot [in Delirium]. It was like killing of [sic] Peeta (from the Hunger Games) or Edward (from Twilight)" (July 11, 7:44 p.m.). Consequently, intertextuality was a consistent undertone of these emotionally driven responses, as students seemed to enjoy comparing books in the forums and making recommendations for further reading, as neither books from The Hunger Games or Twilight series were a part of this program's book club readings. Further, personal responses such as these were present from the start of the book club discussions, suggesting an initially high level of comfort with the online space that persisted until the close of the summer reading program.

Along with explicit responses describing emotions, some students used the book clubs to indulge personal connections through emotive expression. For example, Sam, in posting a response to Wait Till Helen Comes, used multiple techniques to communicate her emotional reaction to another student's previous post that the main character, Molly, was annoying. Sam posted the following:

I agree with you about Molly. She was kind of annoying at times! I will say, though there were plenty of times I wanted to jump into the book and -BONK- her upside the head and tell her to do something about it instead of just sit there complaining. I also kind of understand how it feels to not have a parent believe you and it is practically impossible to change their minds once their [sic] set on something (though I guess teens do it to...heh...). I also agree that it wasn't necessarily "scary" as it was suspenseful (is that the right term???). (June 28, 10:10 p.m.)

Although Sam continued to use formal language in much of this post, she confided in her book club that she has had similar feelings to Molly's in regard to her relationship with her parents.

Considering perspectives. Other students adopted such personal and expressive stances through threaded discussion surrounding how they might feel if they were in the place of a character, what Ivey and Johnston (2013) call "social imagination" (p. 262), to make connections with text and one another. This is exemplified in the following exchange between three students about Maze Runner:

Amy: I would have felt the same way as Thomas did and be confused and angry. Everything would have felt so surreal and imaginary that I would think I am dreaming. I would also have the same enthusiasm as Thomas and have that urge to explore and learn more about the mysterious place. (July 25, 7:26 p.m.)

Melissa: I think I would have felt fear because of the feeling of not knowing about who I really am, how I got there, WHY I'm there, and where I am. (July 26, 8:27 p.m.)

Melissa: I would feel confused and want to get as many answers as I could. I would feel angry at anyone if they did not answer my questions even thought [sic] they know the answer. Also, I would try to remember as much as I could while being stuck in the box. (July 27, 4:37 p.m.) 


\section{Out-of-School Reading and Literature Discussion: \\ An Exploration of Adolescents' Participation in Digital Book Clubs}

Frank: I would feel fear because I couldn't remember anything... (July 27, 4:39 p.m.)

Exchanges such as this were common as students often took the perspective of a character in the novel being discussed and shared their feelings to connect their personal stance to the character's. Further, these types of emotive discussions often prompted increased participation, as exemplified in the previous exchange that took place in the Dystopian book club. We also note that this forum had the most posts and discussion members, and discussion was dominated by students' emotional responses and connections to text.

Posing questions to elicit personal response. Finally, analysis indicated students asked questions to prompt personal connection, which served to further facilitate socially connected discussion focused on emotion. For example, Bryce used questioning to stimulate further response by posting, "I like Delirium, because it creates a world in the future so different from ours...This is an interesting world...,but it's not a world I'd want to live in. Would you want to live in this world?" (July 8, 10:06 a.m.). Unlike the efferent-response questions referred to in the previous section, questions such as Bryce's sought to prompt students to consider their own reactions and opinions to place themselves in the literary world they were discussing. Often these types of questions allowed students to draw connections between their own lives and the literature and facilitated discussion, such as Frank's and Melissa's:

Frank: Though this world has its pluses - not having to worry about your future and knowing when you get "cured" everything will be fixed. I would definitely not want to live in it because love is such a magical thing that should not be discouraged. (July 14, 11:42 p.m.)

Melissa: Me too, love isn't something that can be cured. Love is something that is not only in your mind and in your heart, but it's in your spirit. (July 15, 3:21 p.m.)

Students' questioning often encouraged agreement or disagreement to convey personal opinions and connections. For example, in a conversation about the behavior of Molly in Wait Till Helen Comes, Amy disagreed with others' opinions and began questioning to encourage others to weigh in:

Amy: I am going to have to disagree with the statements about Molly. I mean, what could she do? She tried telling her mom/Dave, didn't work. If she spent more time with her mom, Heather would bother her more about 'needing mommy'. She had a somewhat good feeling about Dave, but that vanished when he took Heather's side way too much. What else could she do? (June 29, 7:44 p.m.)

Amy's contribution incited responses from Grey and Sam, who elaborated on Amy's ideas by providing evidence that they read her response.

Grey: I really doubt if she spent more time with her mom Heather would have complained. Heather hated her mom. (June 29, 8:50 p.m.)

Sam: I understand what you're saying, after all we all saw (or read I suppose) how her mother took Dave and Heather's side...I have to say I did not like how their mother chose her relationship with Dave over the welfare of her children, and Dave was just plain mean to them. (June 29, 11:54 p.m.) 
Students consistently used agreement or disagreement statements to sustain discussion throughout the book club forums not only to prompt discussion but also to reveal others' opinions and ideas about text content. These types of exchanges encouraged others in the book club to tap into their emotional or personal responses to literature, highlighting how students used the OSN as a personal—as well as formal—space for discussion about YA literature.

\section{Discussion}

The online book clubs seemed to prompt adolescents to spontaneously adopt online discussion techniques that hybridized formal discussion practices with more personal practices to encourage emotive transaction with text. The fluidity with which students moved among these practices and the characteristics of their responses in the online book clubs contribute important insights into our understanding of how students participate in online book clubs with limited guidance from adults. Further, we consider how teachers may utilize such practices in literature instruction to promote engagement in online literature discussion. We discuss here these insights.

Formality in language and response set the tone for digital writing practices across book clubs in this study. Students were intentional about the language used in their responses. They consistently demonstrated that they valued using grammatically and mechanically correct traditional language to clearly communicate their own interpretations and personal experiences with the text. This finding contrasted with Turner and colleagues' (2014) conclusions regarding adolescents' tendencies to use an abbreviated and symbol-driven language when engaging in social digital writing. We considered that this may have been because, unlike face-to-face book club conversations, the OSN enabled students to share at times that were convenient to them and when they could reflect on or edit a response before sharing it with others, similar to Wolsey and Grisham's (2007) findings. Further, all but two of the students were strangers to one another prior to the study. Students may have used formal language to clearly express their opinions and create online personae as knowledgeable readers prepared to engage in exchange about literature to create specific identities in out-of-school contexts, as Alvermann et al. (2012) found. Without being able to interview students about this formality, due to the voluntary nature of participation in this program and students not being available to meet with us following its conclusion, we considered that students wanted to present their ideas and selves in a manner that was appealing for the space and for their audience. For instance, although the program was set outside of school, the basic premise of discussing literature through a public library program facilitated by university researchers may have been perceived as school-like by students, particularly as many students were participating in the program for reasons outside of simply wanting to discuss literature for pleasure or interest. Yet, almost all indicated they enjoyed reading and discussing literature, and as noted previously, their high level of comfort in revealing emotion and discussing personal reactions somewhat offset the potential of the library and our university affiliations to be major influential factors in discussion. Still, those factors must be considered.

Students also may have been wary of deviating from the tone and style of initial discussion posts. Students could navigate among book club discussions in the online social network before posting their responses and participate in multiple book clubs simultaneously, which seemed to create a consistent tone and writing style across book clubs. This explanation is powerful in examining how initial interactions and opportunities to participate in multiple book club discussions shape an online space. This study suggests initial interactions in the book clubs were 
important to shaping the type of discussion that took place over the course of the summer reading program, and it is essential to consider development of online spaces for discussion in classrooms and the types of discussion and literacies teachers want to promote. For example, the students in this study were self-described good readers and enjoyed reading, and discussion data indicated they had a firm understanding of formal writing and language. However, students who struggle with formal writing and discussion techniques may be turned off by these types of book clubs. As teachers step into a facilitator role in online settings (Leu et al., 2013), they must consider the tone being set for the online discussion space, either by them or by students, and how to engage all literacy learners in the space and encourage multiple types of accepted discussion techniques to promote new literacies.

Educators may consider promoting text-to-self and text-to-world connections, as students clearly favored discussion that was personal and promoted text-to-self connections. The online book clubs in this study highlighted the multifaceted nature of adolescents' participation in online discussion as they formally considered and responded to new information and negotiated among each other to both defend and revise their interpretations and responses to a text outside of a gradeoriented classroom space in a personal and often emotive manner, confirming Rosenblatt's (1995) longstanding support for promoting student transaction with text in literary response. Rather than adopting and rotating through the traditional literature-circle student roles, often assigned in faceto-face discussion (Daniels, 2002), students simultaneously self-adopted multiple discussion techniques that allowed for their transactions with the text to be the focus of discussion. For example, students adopted discussion practices to promote their own interests to facilitate a particular type of online space, choosing to ignore some aspects of discussion while emphasizing others, which is more difficult to accomplish in a face-to-face setting. Rarely did a question arise about a specific plot point or clarification, but when it did, students either responded to these clarification questions quickly and with little elaboration or ignored the questions altogether. Instead, students were drawn to more meaningful conversation in which they could make personal connections to the text and with one another, similar to the fan fiction space described by Curwood (2013). Such connections drew parallels between these book clubs and affinity spaces, noting the importance of students' self-selection of literature to engage in more meaningful and connected discussion. Finally, the OSN allowed students extended time to join multiple conversations and consider different viewpoints simultaneously. These features highlighted the importance of asynchronicity (Larson, 2009), extended time in which to read and respond to literature, and spatiotemporal affordances of such a platform for facilitating meaningful and multiple discussions about literature.

\section{Limitations}

Although this study yielded promising results for online summer reading programs to connect traditional and online literacies, limitations must be considered. First, we did not compare the OSN book clubs to face-to-face book clubs and can only offer results regarding how an OSN was utilized in this summer reading program. Additionally, participation in this study and the summer reading program was voluntary, and we were unable to follow up with participants to interview them on their experiences and discussion techniques, as parents would have had to drive participants to a central location to meet with us. Further, our attempts to set up phone interviews were unsuccessful, possibly due to back-to-school activities and schedules.

We also note that our population of students was largely homogenous, consisting primarily of Caucasian female adolescents. Students in our study did not indicate a struggle with reading or 
discussing books, and most students indicated they enjoyed reading. Further, as the library director created the list of books, we do not have data that explicitly addresses the rationale for selecting those texts. We cannot address the extent to which book characteristics affected the type of discussion and response that occurred on the OSN.

The students also met us during the initial orientation meeting and knew we were affiliated with a university and worked in education. Further, we did provide broad initial prompts to move students from discussion about one book to the next, following the discussion schedule. Our findings could be informed by future research that attempts to diversify the population engaged in an online summer reading program and the roles adults play in facilitating discussion in a summer reading OSN. Also, even though students sometimes made book recommendations and remarked about books being made into films, they did not incorporate hyperlinks, images, or sound features (which are all features offered on the Ning) into their posts to elaborate their written responses. We did not explicitly encourage or instruct them in how to use these tools, but we did show students where to access the tools in the overview of the Ning network at the orientation meeting. Further, the Ning's structure was similar to Facebook, which all students indicated that they used. However, we did not collect data regarding students' use of such tools on Facebook or other online social networks. Therefore, we note the lack of these practices and this data as limitations in this study and encourage future research in online summer reading programs to explore how to better integrate all features of an OSN into literature discussions and the decisions students make to include or exclude these features from their online writing.

\section{Conclusions}

Leu et al. (2013) contended that in new literacy classrooms the role of the teacher may change but becomes increasingly important. We concur, but we also consider how students' discussion techniques of YA literature in online book clubs transformed literature discussion to become both formal and personal, and we also consider what specific roles the teacher may play to support such discussion in a classroom setting. Additionally, we found that online spaces with minimal adult support have strong potential for encouraging academic discussions of literature: Students participating in the OSN kept their discussion focused on the books and consistently utilized formal writing skills, while simultaneously employing sophisticated discussion skills to navigate and respond in the book clubs. These findings suggest minimal teacher involvement in online discussion spaces can yield thoughtful discussion about literature, if students are engaged in the literature being discussed. Under these specific circumstances, the absence of a teacher within a literature discussion seemed to be beneficial to students. Students explored their own questions and ideas, engaged in sustained discussions about literature, listened more actively to each other, developed their own strategies to initiate discussions, and encouraged each other to share or expand their ideas. The minimal role of adults in online discussion spaces seemed to offer increased opportunities for engaging students in out-of-class online conversations about literature, which suggests promising possibilities for including an additional learning project or activity in what are already full curricular schedules.

Thus, continual adult guidance may not always be necessary for meaningful discussions about literature in online spaces, but findings do suggest a need for teacher scaffolding for adolescents to sustain productive discussions of literature. As an example, we noticed that while some students in our study asked questions that prompted extensive discussion about their books, 
other students asked questions that received no responses. To prepare all students for engaging in discussions about literature, it may be necessary for teachers to model and integrate into instruction how to ask meaningful, thought-provoking questions, such as inferential or analytical questions into instruction (see Serafini, 2004).

This study also suggests positive implications for including YA-literature-focused online book clubs and out-of-class literature discussions to support literacy learning. Although book clubs and literature discussion have fallen somewhat out of favor in instruction in recent years, primarily due to a decreased focus on these literacy skills in standardized testing, the skills promoted through such activities are important for students to build academic literacy, for example, in English (Langer, 2011). Students in this study relied on traditional literary analysis skills, such as identifying literary elements, making specific intra- and intertextual connections, and using the text to support their claims. As a result, literary elements such as setting, characterization, and theme were prevalent topics throughout the conversations. Students grappled with issues of character motivation, the influence of setting on the plot, and overall thematic message, and they explained and revised their positions as a result of extended conversation with other students. Further, there were no established expectations for posting a response, so it is likely that students' responses were the result of genuine interest in engaging other students and in the literature selection (Curwood, 2013). Thus, establishing online book clubs focused on popular YA literature in English classrooms to supplement a traditionally canonical curriculum may authentically build literary skills prioritized in the study of English literature and support authentic learning experiences.

As noted previously, students may spontaneously adopt a more formal tone in online book clubs, as did students in this library program. However, we also encourage teachers whose students do not adopt such a tone, (e.g., students who struggle with writing or discussion) to consider the content being promoted in the discussion, as informal digital writing may still promote important thinking about a topic (Turner et al., 2014). Teachers may also consider how digital tools, such as video and audio recordings, might support all students' participation in an OSN book club and offer alternative routes to discussion for those who struggle with writing.

Finally, findings suggested that participation in an OSN could promote more concentrated student engagement with reading YA literature. Ivey and Johnston (2013) reported multiple dimensions of engaged reading as a result of interviewing and observing eighth-grade students in classrooms where self-selected YA literature was a predominant feature of the English curriculum. Several of these dimensions were also observed in our study. For instance, they noted that engagement was demonstrated by "widespread talk" about books (p. 261); we saw this often in our study when students made connections between book club selections and other titles they knew and when they recommended books to each other. Additionally, like us, they identified "social imagination," or the ability to assume another person's perspective, as a dimension of engagement. The parallels between Ivey and Johnston's findings and ours suggest that OSNs may be a useful tool for promoting reading and literary engagement with adolescents. Moreover, the ability of students to join multiple book clubs, a feature distinct to an OSN, may provide increased opportunities for engagement. Thus, we consider that the online book clubs in our study have the potential to encourage the sort of relational and socially interactive engagement with books called for in recent research. 


\begin{abstract}
About the Authors
Jamie Colwell is an associate professor in the Darden College of Education at Old Dominion University. Her research interests include digital literacy and disciplinary literacy, primarily focusing on adolescents and preservice teachers.

Lindsay Woodward is an assistant professor at Drake University. Her research focuses primarily on the intersection of technology and literacy, particularly in the fields of adolescent literacy and professional development.

Amy Hutchison is an associate professor at George Mason University. She studies the use of technology for educational innovation.
\end{abstract}

\title{
Acknowledgements
}

This research was supported by a Summer Research Fellowship through the Old Dominion University Research Foundation and a Dollar General Summer Reading Grant. 


\section{References}

Allington, R. L., \& McGill-Franzen, A. (Eds.). (2013). Summer reading: Closing the rich/poor reading achievement gap. New York: Teachers College, Columbia University.

Alvermann, D. E. (2008). Why bother theorizing adolescents' online literacies for classroom practice and research? Journal of Adolescent \& Adult Literacy, 52(1), 8-19.

Alvermann, D. E., Marshall, J. D., McLean, C. A., Huddleston, A. P., Joaquin, J., \& Bishop, J. (2012). Adolescents' web-based literacies, identity construction, and skill development. Literacy Research and Instruction, 51(3), 179-195. doi:10.1080/19388071.2010.523135

*Baltazar, A. (2009). Tiny titans: Welcome to the treehouse. New York: DC Comics.

*Bauer, J. (2013). Almost home. New York: Viking.

Black, R. W. (2009). Online fan fiction, global identities, and imagination. Research in the Teaching of English, 43(4), 397-425.

Buck, A. (2012). Examining digital literacy practices on social network sites. Research in the Teaching of English, 47(1), 9-38.

*Carter, A. (2007). I'd tell you I love you, but then I'd have to kill you. New York: Hyperion.

*Cashore, K. (2009). Graceling. Orlando, FL: Houghton Mifflin Harcourt.

*Cass, K. (2013). The selection. New York: HarperCollins.

Crystal, D. (2001). Language and the Internet. New York, NY: Cambridge University Press.

Curwood, J. S. (2013). The hunger games: Literature, literacy, and online affinity spaces. Language Arts, 90(6), 417-427.

Daniels, H. (2002). Literature circles: Voice and choice in book clubs and reading groups (2nd ed.). York, ME: Stenhouse.

*Dashner, J. (2010). The maze runner. New York: Delacourt Press.

Day, D., \& Kroon, S. (2010). “Online literature circles rock!": Organizing online literature circles in a middle school classroom. Middle School Journal, 42(2), 18-28.

English, C. (2007). Finding a voice in a threaded discussion group: Talking about literature online. English Journal, 97(1), 56-61.

*Forester, V. (2010). The girl who could fly. New York: Square Fish.

Gee, J. P. (2003). What video games have to teach us about learning and literacy. New York: Palgrave.

Gee, J. P. (2004). Situated language and learning: A critique of traditional schooling. New York: Routledge.

Gee, J. P. (2005). Learning by design: Good video games as learning machines. E-learning and Digital Media, 2(1), 5-16. doi:10.2304/elea.2005.2.1.5

Gee, J., \& Hayes, E. (2013). Nurturing affinity spaces and game-based learning. In J. Gee, Good video games and good learning: Collected essays on video games, learning and literacy (2nd ed., pp. 103-124). New York, NY: Peter Lang. 
Grisham, D. L., \& Wolsey, T. D. (2006). Recentering the middle school classroom as a vibrant learning community: Students, literacy, and technology intersect. Journal of Adolescent \& Adult Literacy, 49(8), 648-660.

*Hahn, M.D. (2008). Wait till Helen comes. New York: Clarion Books.

Hutchison, A., \& Henry, L. (2010). Internet use and online reading among middle-grade students at risk of dropping out of school. Middle Grades Research Journal, 5(2).

Ivey, G., \& Johnston, P.H. (2013). Engagement with young adult literature: Outcomes and processes. Reading Research Quarterly, 48(3), 255-275.

*Kibushi, K. (2008). Amulet. New York: Scholastic, Inc.

Lankshear, C., \& Knobel, M. (2007). A new literacies sampler. New York: Peter Lang.

Lankshear, C., \& Knobel, M. (2011). New literacies: Everyday practices and classroom learning (3rd ed.). Maidenhead, UK: Open University Press.

Larson, L. C. (2009). Reader response meets new literacies: Empowering readers in online learning communities. The Reading Teacher, 62(8), 638-648. doi:10.1598/RT.62.8.2

Leander, K., \& Frank, A. (2006). The aesthetic production and distribution of image/subjects among online youth. E-learning, 3(2), 185-206.

Leu, D. L., Kinzer, C. K., Coiro, J., Castek, J., \& Henry, L. A. (2013). New literacies: A duallevel theory of the changing nature of literacy, instruction, and assessment. In D. E. Alvermann, N. J. Unrau, \& R. B. Ruddell (Eds.), Theoretical models and processes of reading (6th ed., pp. 1150-1181). Newark, DE: International Reading Association.

*Mass, W. (2012). Twice upon a time: Rapunzel. New York: Scholastic, Inc.

Mehan, H. (1979). "What time is it, Denise?": Asking known information questions in classroom discourse. Theory Into Practice, 28(4), 285-294.

Moje, E. B. (2009). A call for new research on new and multi-literacies. Research in the Teaching of English, 43(4), 348-362.

*Moore, K., Reed, T., \& Reed, L. (2013). Amber house. New York: Scholastic.

Nasir, N. S., \& Cooks, J. (2009). Becoming a hurdler: How learning settings afford identities. Anthropology \& Education Quarterly, 40(1), 41-61. doi:10.1111/j.15481492.2009.01027.x

National Governors Association (2010). Common Core standards for English language arts and literacy in history/social studies, science, and technical subjects. Retrieved from http://www.corestandards.org/ELA-literacy/

*Ness, P., \& Kay, J. (2013). A monster calls. Somerville, MA: Candlewick Press.

*Oliver, L. (2012). Delirium. New York: HarperCollins.

Öztok, M. (2016). Cultural ways of constructing knowledge: The role of identities in online group discussions. International Journal of Computer-Supported Collaborative Learning, 11(157), 157-186. doi:10.1007/s11412-0169233-7 
Patton, M. Q. (2002). Qualitative research and evaluation methods (3rd ed.). Thousand Oaks, CA: Sage.

Pitcher, S. M., Albright, L. K., DeLaney, C. J., Walker, N. T., Seunarinesingh, K., Mogge, S., ... Dunston, P. J. (2007). Assessing adolescents' motivation to read. Journal of Adolescent \& Adult Literacy, 50(5), 378-396.

*Poblocki, D. (2012). The ghost of Graylock. New York: Scholastic.

Rosenblatt, L. M. (1995). Literature as exploration (5th ed.). New York: Modern Language Association.

*Rush, J. (2013). Altered. New York: Little, Brown and Company.

Scharber, C. (2009). Online book clubs: Bridges between old and new literacies practices. Journal of Adolescent \& Adult Literacy, 52(5), 433-437.

*Schreiber, J. (2011). Au revoir, crazy European chick. New York: Houghton Mifflin Harcourt.

*Selznick, B. (2011). Wonderstruck. New York: Scholastic.

Serafini, F. (2004). Lessons in comprehension. Portsmouth, NH: Heinmann.

Short, K., Kaufman, G., Kaser, S., Kahn, L. H., \& Crawford, K. M. (1999). "Teacher-watching": Examining talk in literature circles. Language Arts, 76(5), 377-385.

*Spiegelman, A. (2006). Maus. New York: Pantheon Books.

Stewart, M. A. (2014). Social networking, workplace, and entertainment literacies: The out-ofschool literate lives of newcomer Latina/o adolescents. Reading Research Quarterly, 49(4), 365-369.

Thomas, D. R. (2006). A general inductive approach for analyzing qualitative evaluation data. American Journal of Evaluation, 27, 237-246.

Turner, K. H., Abrams, S. S., Katic, E., \& Donavan, M. J. (2014). Demystifying digital: The what and why or the language teens use in digital writing. Journal of Literacy Research, 46(2), 157-193.

West, K. C. (2008). Weblogs and literary response: Socially situated identities and hybrid social languages in English class blogs. Journal of Adolescent \& Adult Literacy, 51(7), 588598.

Wolsey, T. D., \& Grisham, D. L. (2007). Adolescents and the new literacies: Writing engagement. Action in Teacher Education, 29(2), 29-38.

*Young, M. (2012). Dust lands: Blood red road. New York: Margaret K. McElderry Books.

* Indicates a book club book title. 


\section{Appendix A}

\section{Summer Reading Survey}

Please read each prompt and bubble in one response for each prompt.

Next school year, I will be in
○ sixth grade
O seventh grade
$\circ$ eighth grade

I am a
○ Female
○ Male

My race/ethnicity is

- African-American

- Asian/Asian American

- Caucasian

- Hispanic

- Native American

- Multi-racial/Multi-ethnic

O Other: Please specify

1. My friends think I am
○ a very good reader
- a good reader
- an OK reader
o a poor reader

2. Reading a book is something I like to do.
o Never
- Not very often
- Sometimes
○ Often

3. I read

- not as well as my friends

○ about the same as my friends

$\circ$ a little better than my friends

$\circ$ a lot better than my friends
6. I tell my friends about good books I read.

- I never do this

- I almost never do this

- I do this some of the time

- I do this a lot

7. When I am reading by myself, I understand

$\bigcirc$ almost everything I read

O some of what I read

- almost none of what I read

$\circ$ none of what I read

8. People who read a lot are

$\circ$ very interesting

$\circ$ interesting

- not very interesting

$\circ$ boring

9. I am

o a poor reader

O an $\mathrm{OK}$ reader

o a good reader

o a very good reader

10. I think libraries are

- a great place to spend time

$\circ$ an interesting place to spend time

- an OK place to spend time

$\circ$ a boring place to spend time

11. I worry about what other kids think about my reading
$\circ$ every day
- almost every day
o once in while
o never 
4. My best friends think reading is

$\circ$ really fun

$\circ$ fun

- OK to do

○ no fun at all

5. When I come to a word I don't know, I can

○ almost always figure it out

$\circ$ sometimes figure it out

$\bigcirc$ almost never figure it out

$\circ$ never figure it out

13. When my teacher asks me a question about what I have read, I

O can never think of an answer

$\circ$ have trouble thinking of an answer

- sometimes think of an answer

○ always think of an answer

14. I think reading is
$\circ$ a boring way to spend time
$\circ$ an $\mathrm{OK}$ way to spend time
$\circ$ an interesting way to spend time
$\circ$ a great way to spend time

15. Reading is
o very easy for me
$\circ$ kind of easy for me
o kind of hard for me
o very hard for me

16. As an adult, I will spend

$\circ$ none of my time reading

o very little time reading

○ some of my time reading

○ a lot of my time reading
12. Knowing how to read well is

○ not very important

○ sort of important

○ important

o very important

17. When I am in a group talking about what we are reading, I

○ almost never talk about my ideas

○ sometimes talk about my ideas

- almost always talk about my ideas

o always talk about my ideas

18. I would like for my teachers to read out loud in my classes during the school year
○ every day
○ almost every day
$\circ$ once in a while
$\circ$ never

19. When I read out loud I am a

o poor reader

- OK reader

○ good reader

○ very good reader

20. When someone gives me a book for a present, I feel
$\circ$ very happy
○ sort of happy
○ sort of unhappy
○ unhappy

We would like to know more about you and your reading! Please answer the questions below to tell us more about yourself as a reader.

1. Why did you decide to participate in this online book club?

2. What is the most interesting story or book you have read recently? How did you find out about this story or book? 
3. Did you read anything at home yesterday? What?

4. Who is your favorite author? Why is this author your favorite?

5. What are some things that get you really excited about reading?

6. Who gets you really interested and excited about reading?

7. Do you have a computer in your home?

8. If yes, please answer the following:

a. How much time do you spend on the computer a day?

b. What do you usually do on the computer?

c. What do you like to read when you are on the Internet?

9. If you do not have a computer in your home, please answer the following:

a. What would you like to do with a computer if you had one?

b. Is there anything on the Internet that you would like to be able to read?

10. Do you share and discuss books, magazines, or other reading materials with your friends outside of school? If so, what do you share?

11. Do you write letters or email to friends or family? If so, how often?

12. Do you belong to any clubs or organizations for which you read and write? If so, which one(s) do you belong to? 
Out-of-School Reading and Literature Discussion:

An Exploration of Adolescents' Participation in Digital Book Clubs 